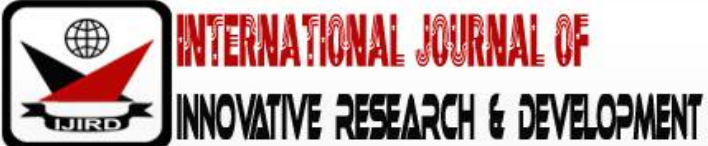

ISSN 2278 - 0211 (Online)

\section{Geospatial Assessment of Covid-19 Spread in Nigeria}

Olufemi Felix Iyiola
Principal Lecturer, Department of Surveying and Geoinformatics,
Federal School of Surveying, Oyo, Nigeria
Ayodeji Ajani
Senior Lecturer, Department of Geographic Information System and Cartography,
Federal School of Surveying, Oyo, Nigeria
Latifat Olaide Oyelakin
Lecturer, Department of Surveying and Geoinformatics,
Federal School of Surveying, Oyo, Nigeria

\begin{abstract}
:
The first confirmed case of COVID-19 was reported in Nigeria on 27th February 2020, the infected person is a 44-yearold Italian citizen who arrived at the Murtala Muhammed International Airport, Lagos on $24^{\text {th }}$ February 2020. The number of confirmed cases rose to 8,344 with 249 deaths, 2,385 discharged cases and 5,710 active cases (https://covid19.ncdc.gov.ng, accessed on 27th May 2020 10:45am) within thirteen weeks the first case was reported. The spread of COVID-19 as wildfire has covered thirty-four (34) states of the federation including the Federal Capital Territory (FCT). The spread in Nigeria with an estimated population of over 206 million has been a major concern to the Federal and State governments. Lagos and Kano are the most populous states and have recorded highest number of confirmed cases in the country. Nigeria Centre for Disease Control (NCDC) released guidelines to reduce the spread of COVID-19 which include social distancing, frequent washing of hands, avoiding crowded places and physical contact, use of face masks, etc. Records have shown that the worst-hit places are urban centres such as Lagos, Ibadan, Kano, Oshogbo, FCT, Kaduna, etc. COVID-19 risk factors in Nigeria include international exposure, high poverty level in the country, poor healthcare systems, population and crowded urban areas, internally displaced persons. This study aimed at using geospatial technologies to assess the spatial spread of COVID-19 in Nigeria while the objectives involved identifying risk factors, urban land use patterns, household living conditions and health facilities in Nigeria. Methodology included the use of administrative map of Nigeria, projected population data and COVID-19 data to generate land use map, population density and other products in GIS environment. The study recommended that both federal and state government should equip the treatment centres with basic health facilities and motivate health workers for optimal performance. Government should also assist farmers with seedlings, fertilisers and soft loans to ensure food security in the country.
\end{abstract}

Keywords: Coronavirus, disease, healthcare system, geospatial assessment

\section{Introduction}

The first confirmed case of COVID-19 was reported in Nigeria on 27th February 2020, the infected person is a 44year-old Italian citizen who arrived the Murtala Muhammed International Airport, Lagos on 24th February 2020. The federal government immediately strengthened surveillance at the five international airports in the country with the aim of preventing further spread of the virus. The federal government also set up Presidential Task Force (PTF) on COVID-19 to mitigate the impact of the virus if it eventually spreads to the country. The Task Force in collaboration with the Federal Ministry of Health instituted several measures to curtail the spread of the virus and protect the citizens which included a ban on international flights and imposed a lockdown on non-essential activities in the Federal Capital Territory (FCT), Ogun and Lagos states.

The Nigeria Centre for Disease Control (NCDC) has the mandate to lead the preparedness, detection and response to infectious disease outbreaks and public health emergencies in the country. NCDC's core functions are to:

- Prevent, detect and control disease of public health importance

- Coordinate surveillance systems to collect, analyse and interpret data on diseases

- Support state in responding to small outbreaks

- Develop and maintain a network of specialized laboratories

- Conduct, collate, synthesize and disseminate public health research to inform policy

- Lead Nigeria's engagement with the international community on diseases of public health relevance (https://ncdc.gov.ng/ncdc) 
NCDC established twenty-six (26) laboratories with the capacity to test for COVID-19 in the country, these laboratories are well equipped with reagents and other facilities for testing.

The number of confirmed COVID-19 cases in Nigeria rose to 8,344 with 249 deaths, 2,385 discharged cases and 5,710 active cases (https://covid19.ncdc.gov.ng, accessed on 27th May 2020 10:45am) within thirteen weeks the first case was reported. The virus causes mild to severe respiratory symptoms like fever, cough and difficulty breathing. Since there is no specific treatment yet for COVID-19, NCDC recommended the following to reduce the risk of spread of the virus:

- Frequent washing of hands with soap under running water for at least 20 seconds

- Use of alcohol-based sanitizer if water is not available

- Use of face mask

- $\quad$ Covering of nose and mouth with tissue paper when sneezing/coughing

- Avoiding crowded areas

- $\quad$ Social distancing

\section{Study Area}

Nigeria comprises thirty-six (36) states and the Federal Capital Territory (FCT) located in Abuja (figure 1). Nigeria is referred to as the 'Giant of Africa' due to its population and economy, the country has a projected population figure of over 196 million people in 2019 which made it the most populous country in the continent.

Nigeria has a total area of $937,052 \mathrm{Km}^{2}$ and it shares borders with Niger in the North, Chad in the Northeast, Cameroon in the East and Benin Republic in the West while the Southern Coast is on the Gulf of Guinea in the Atlantic Ocean. Geographical location of Nigeria is between latitudes $4^{\circ} \mathrm{N}$ and $14^{\circ} \mathrm{N}$, and longitudes $2^{\circ} \mathrm{E}$ and $15^{\circ} \mathrm{E}$.

The country is divided into six (6) geopolitical zones namely North West, North East, North Central, South East, South and South West (figure 2). Five most populous cities in the country from largest to smallest are Lagos, Kano, Ibadan, Benin City and Port Harcourt.

Nigeria has a tropical climate with variable rainy and dry seasons, the length of rainy season decreases from south to north. Rainy season lasts from March to November in the South while it last from mid-May to September in the far North. Temperature and humidity remain relatively constant through the year in the south while the seasons vary considerably in the north.

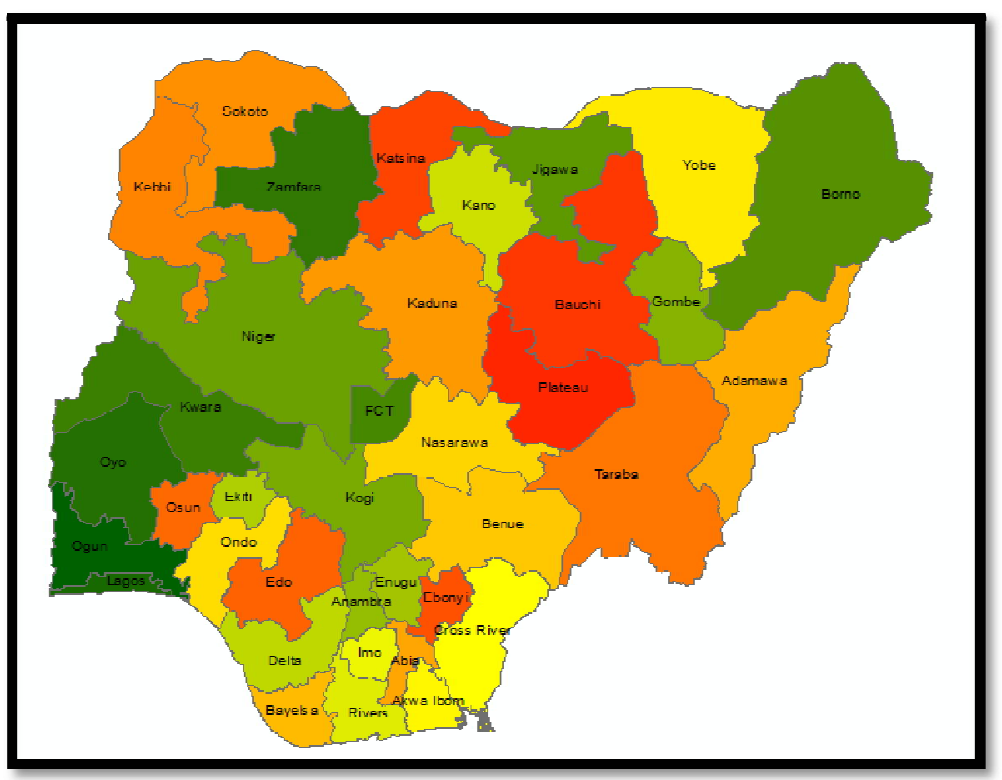

Figure 1: Administrative Map of Nigeria 


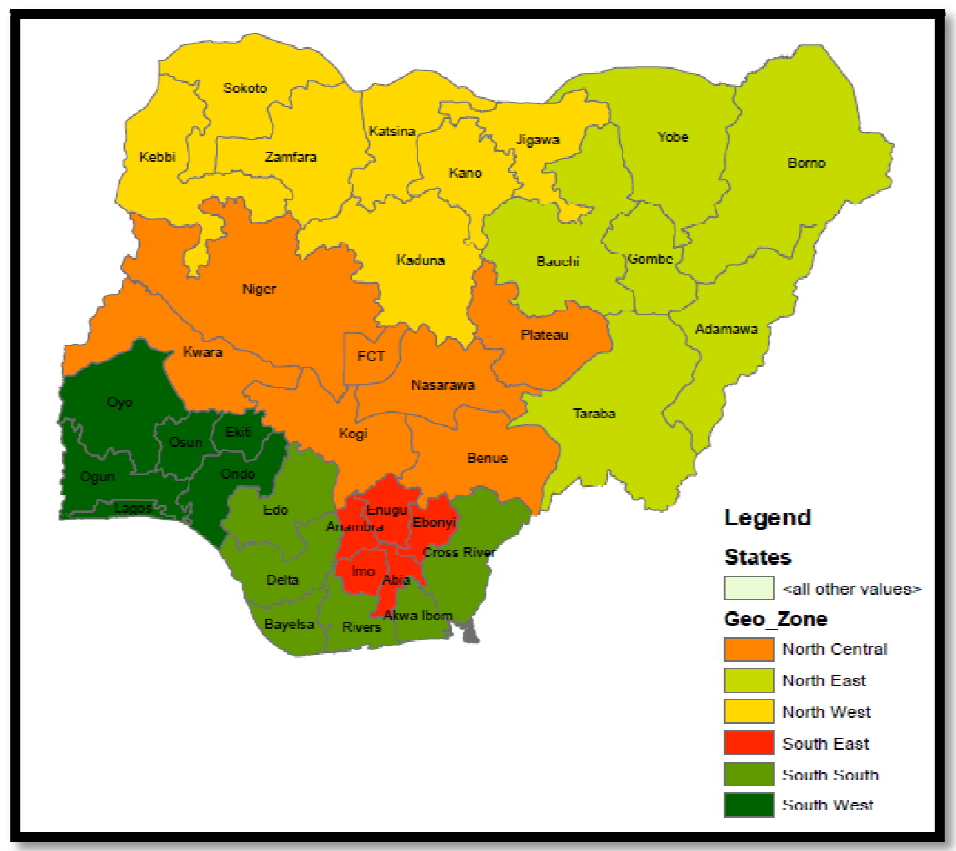

Figure 2: Geopolitical Zones in Nigeria

\section{Methodology}

\subsection{Data and Method}

The administrative map of Nigeria was converted to shape file and attribute data linked to geometric data in Arc GIS. Projected population data for each state of the federation was computed (using equation 1) for the year 2020 from the 2006 population data obtained by the National Population Commission.

$\mathrm{Nt}=\mathrm{Pe}^{\mathrm{r}^{* t}}$ Equation 1

Where,

$\mathrm{Nt}$ is the number of people at a future date

$\mathrm{P}$ is the present population

e is the natural logarithm base of 2.71828

$\mathrm{r}$ represents the rate of growth divided by 100

t represents the time period

Population density was also computed for each state using equation 2. Population density shows how crowded an area is on average in order to figure out resources the area requires.

Population Density $=\frac{\text { Number of People }}{\text { Land Area }}$ Equation 2

This study used COVID-19 daily report from the Nigeria Centre for Disease Control (NCDC) to obtain daily data and to also compute weekly data.

\begin{tabular}{|c|c|c|c|c|}
\hline WEEK & DATE & CONFIRMED & DISCHARGED & DEATHS \\
\hline 0 & 28-Feb & 0 & 0 & 0 \\
\hline 1 & 06-Mar & 1 & 0 & 0 \\
\hline 2 & 13-Mar & 1 & 0 & 0 \\
\hline 3 & $20-\mathrm{Mar}$ & 10 & 1 & 0 \\
\hline 4 & $27-\mathrm{Mar}$ & 53 & 2 & 1 \\
\hline 5 & $03-\mathrm{Apr}$ & 103 & 17 & 1 \\
\hline 6 & $10-\mathrm{Apr}$ & 119 & 30 & 6 \\
\hline 7 & 17-Apr & 154 & 101 & 6 \\
\hline 8 & 24-Apr & 540 & 45 & 18 \\
\hline 9 & 01-May & 951 & 123 & 26 \\
\hline 10 & 08-May & 1980 & 360 & 59 \\
\hline 15 & 15-May & 1533 & 641 & 54 \\
\hline 16 & 22-May & 1816 & 687 & 50 \\
\hline
\end{tabular}

Table 1: Weekly COVID-19 Data 


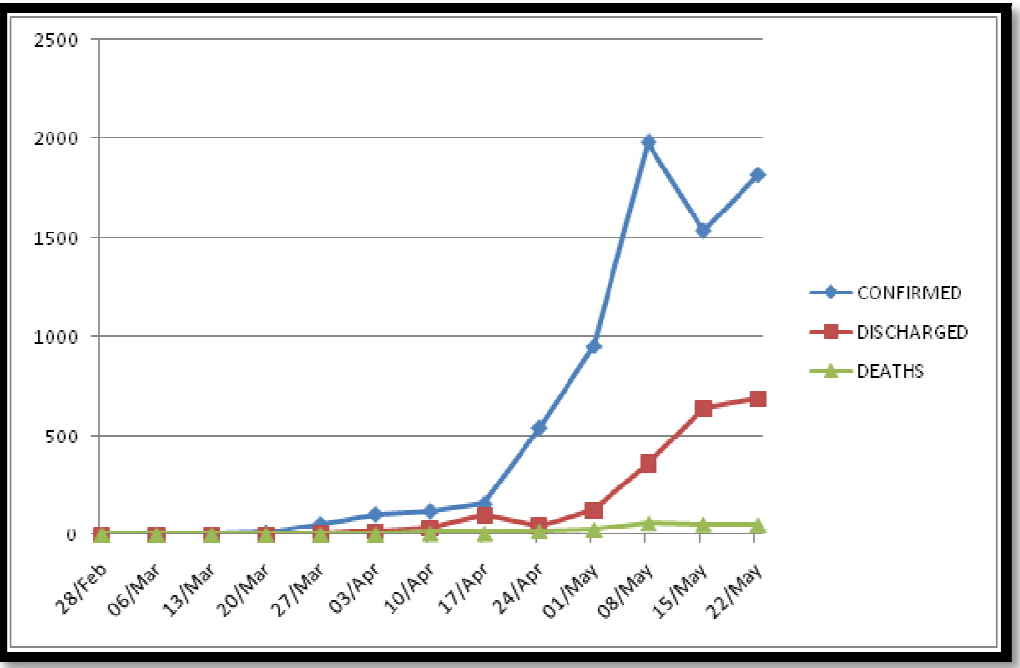

Figure 3: Weekly Occurrence of COVID-19 Cases

Table 1 and figure 3 show that confirmed cases of COVID-19 began to rise rapidly from 17th April, 2020 and the number has not come down. The number of discharged cases began to rise from 1 ${ }^{\text {st }}$ May, 2020 and it is an indication that COVID-19 patients are responding to treatment while the number of deaths recorded within the period is very low. It is imperative to assess the spatial spread of the virus and identify factors responsible for the spread.

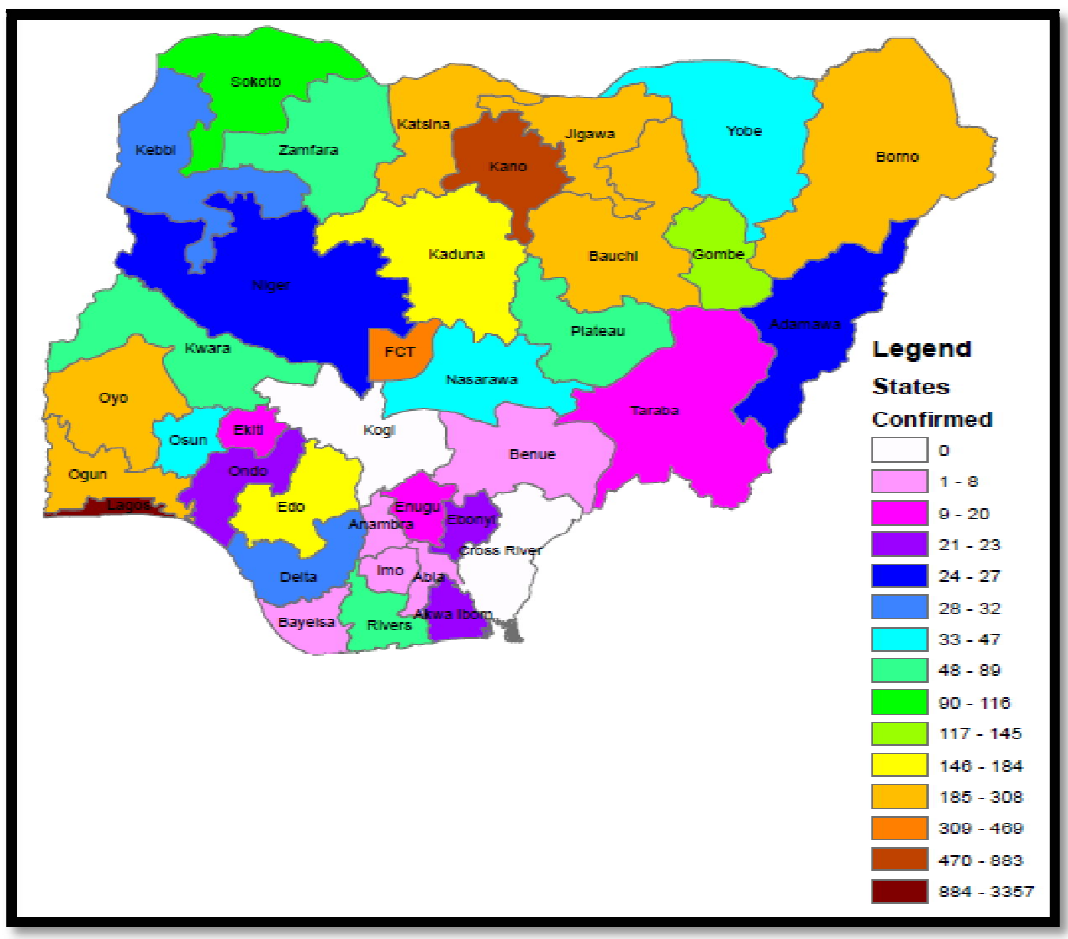

Figure 4: Spread of COVID-19 in the States of the Federation

\section{Spread of Covid-19 in Nigeria}

Figure 4 shows that Lagos State is having the highest number of confirmed cases followed by Kano and Federal Capital Territory (FCT). Next to them are Katsina, Borno, Jigawa, Oyo Bauchi and Ogun States. The risk factors for the spread of COVID-19 in the country which include:

\subsection{International Exposure}

The first and early cases of coronavirus in Nigeria came from international exposure. Nigerians travel abroad for a variety of purposes such as conference, school, medical treatment, business, tourism and trade. According to the United Nations (UN) migration data portal there were $1.3 \mathrm{~m}$ emigrants from Nigeria in 2019. Statistics from the Nigerian Immigration Service (NIS) indicated that the number of foreigners that come into the country is more than those that left the country in the last five years. 2017 annual report by NIS indicated that about 3.51 million foreigners arrived at the country while 3.24 million left the country between 2013 and 2017 . The report also showed that $3.72 \mathrm{~m}$ travellers crossed Nigerian borders through the five international airports, 111 land borders and six seaports within the period. 


\subsection{Population and Crowded Urban Areas}

Citizens who made contacts with these foreigners and Nigerians who arrived at the country from international trips contracted the virus and it continued to spread through community transmission. Highly populated crowded urban areas like Lagos, Kano, FCT, Ibadan, etc. have the highest records of confirmed cases of COVID-19. It is difficult to observe social distancing in crowded places or public transport where buses are overloaded in most cases. Majority of the people in urban areas live in high density residential houses, living conditions in majority of urban areas are poor with many people sleeping in a small room with little or no provision for facilities like toilet, bathroom, access road, drinkable water and adequate ventilation.

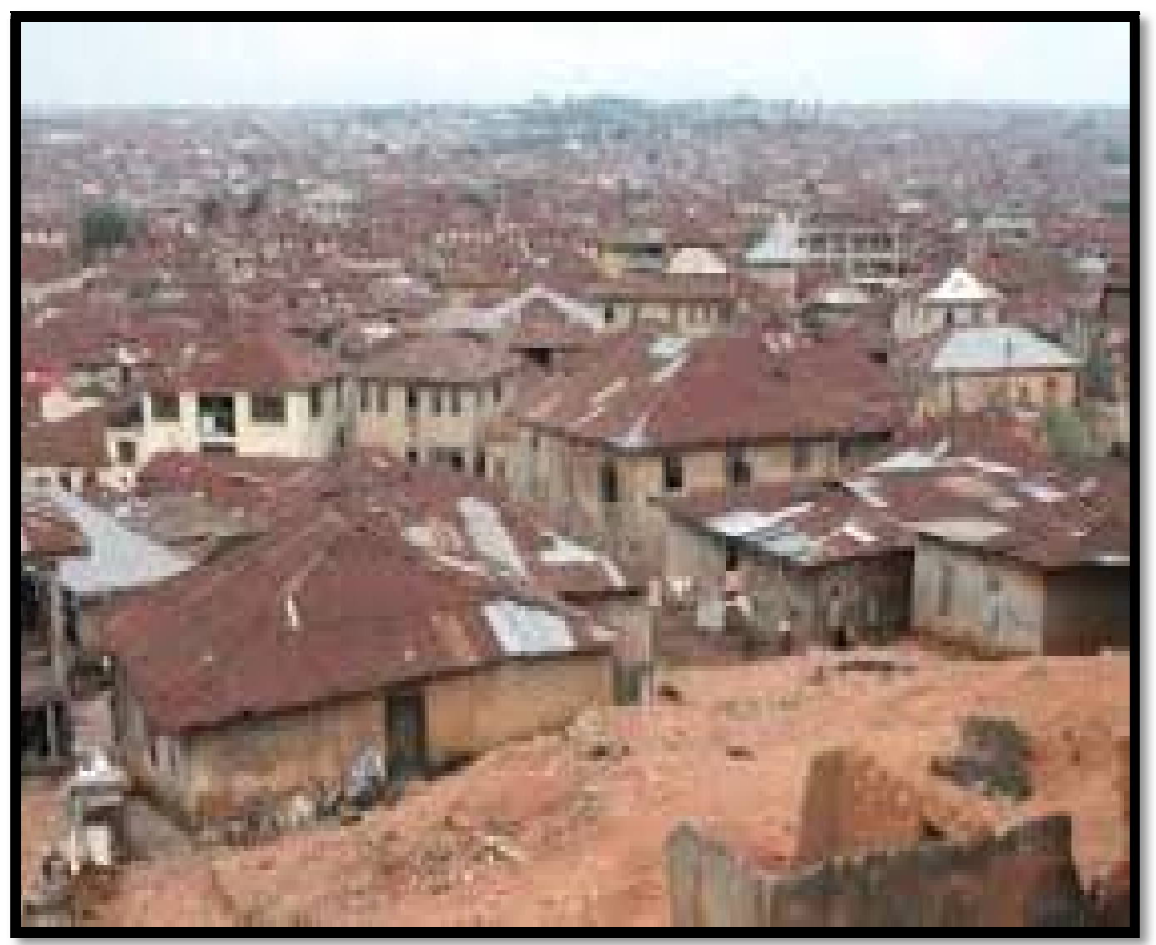

Figure 5: Typical Housing Pattern in Some Parts of Urban Areas

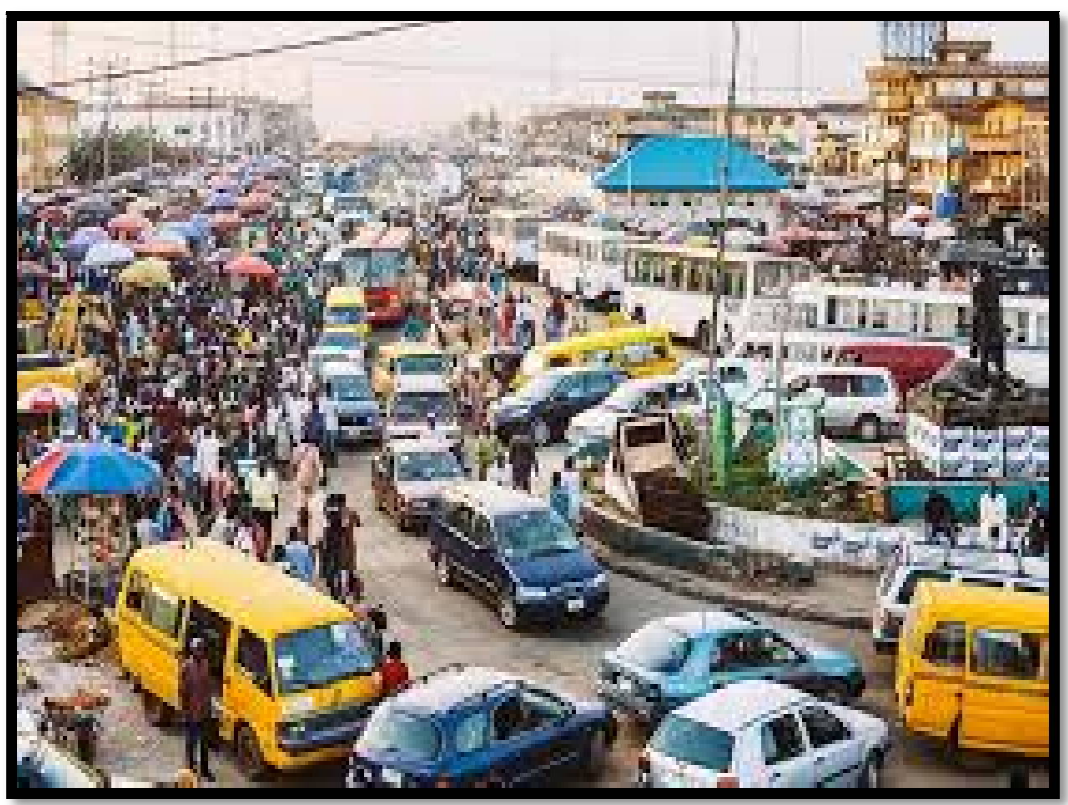

Figure 6: Transportation System in Some Parts of Urban Areas

The population density map shows that Lagos has the highest population density with 3,357persons $/ \mathrm{Km}^{2}$. Lagos is the nation's smallest metropolitan area and a major industrial centre; Kano is also one of the most populous and it is the second largest industrial centre after Lagos. Abuja is in the Capital City of Nigeria located within the Federal Capital Territory; it was built to replace the nation's most populous city of Lagos. Abuja is the fastest growing city on the continent of Africa. COVID-19 appears to spread faster where there is close contact and stay-at-home order is difficult to maintain in areas where residents lack adequate shelter, sanitation and monetary means to stock up food items and other essential items. 


\subsection{High Poverty Level in the Country}

The quality of housing including materials used for roofs, walls, floors, access to road, water and electricity reflects the socioeconomic status of the households and has a direct bearing on the health and welfare of the people. Overcrowding is another problem where a family comprising the father, mother and 2 or 3 children sleep in a small room. Unemployment in the country increases the poverty level and makes citizens vulnerable to coronavirus. Poor citizens cannot afford face masks, hand sanitizers and it is difficult for them to maintain social distancing and live in a clean environment. Most people observing the COVID-19 lockdown lack the food and income that their families will need to survive.

\subsection{Poor Healthcare Systems}

NCDC established 26 laboratories in the country for COVID-19 test and the Centre just tested 46,803 samples (https://covid19.ncdc.gov.ng access date: 27th May 2020 10:45am) out of a population close to 200 million people. The facilities are unevenly spread across the country, the number of testing centres and health personnel are grossly inadequate for the population. Many people have not been tested and citizen who have contracted the virus but asymptomatic would continue spreading the virus because they don't know they are living with it. Health care personnel need to be properly trained to handle COVID-19 cases to ensure optimal healthcare delivery to people. They should be able to identify, test. Isolate and treat people infected in order to reduce the impacts on the society.

\section{Socio-Economic Impacts of Covid-19 in Nigeria}

The COVID-19 pandemic is more than health crisis; it has great impacts on economy and the society. The outbreak will increase poverty level across the globe and the impact will vary from one country to another. The socioeconomic impacts of coronavirus in Nigeria include:

\subsection{Food Security and Agriculture}

Climate change and stay-at-home order will have great impact on food security and agriculture in general. Fear of contracting the virus coupled with lockdown order in the country does not allow farmers to go out during planting season. If is also difficult for farmers to get seedlings, fertilizers and labour. Cost of transportation during this outbreak is high and will adversely affect farm produce at the end of the year.

\subsection{Pressure on Healthcare Facilities}

COVID-19 outbreak brought immense pressure on healthcare facilities. Test kits, personal protective equipment, face masks, hand gloves, etc. are greatly inadequate. Health workers are reluctant to attend to patients for lack of basic health facilities. Symptoms of COVID-19 are similar to that of malaria fever; people with catarrh, cough and fever are also reluctant to go to hospitals.

\subsection{Impact on Economy}

Government offices, banks, businesses, etc. are closed down during this pandemic. Government at all levels could not generate revenues while business owners all sit down at home. The country also face decline in oil prices by almost $60 \%$ during the period. $65 \%$ to $80 \%$ government and export revenues in the country come from oil sector. Exchange rate in the country depreciated with great impact on the prices of commodities.

\subsection{Unemployment}

The outbreak of the virus led to the closure of business, government offices and financial institutions. Many small businesses may not survive or recover from it and may lead to joblessness. Some businesses and financial institutions now discover they can work from home with few people and ICT facilities, some of them are likely to layoff some staff

\subsection{Security Impacts}

The adverse effect of COVID-19 outbreak on peace and security of the country should be looked into. Jobless youths who cannot afford three square meals took to crime and a number of robbery and kidnapping cases were recorded in some parts of the country. Security personnel are engaged in a lot of operations like border patrol, enforcing stay-athome and curfew orders.

\section{Measures Put in Place to Stop the Spread of the Virus}

Nigeria Centre for Disease Control (NCDC), state and federal government put the following measures and guidelines in place to stop the spread of the virus:

- Ban on religious gatherings, parties and night clubs, avoiding crowded areas and social distancing.

- Closure of government offices, businesses, private and government schools

- Establishment of testing, isolation and treatment centres

- Distribution of face masks

- Guidelines on frequent washing of hands or use of alcohol-based hand sanitizer

- Covering of nose and mouth with tissue paper during coughing and sneezing 


\section{Findings}

The study has been able to show that coronavirus came to Nigeria as a result of international exposure as the early cases were from foreigners and citizens who came into the country from international trips and people contracted the virus from them. The virus continued to spread across the country through community transmission.

The study also showed that the virus spread fast in urban and crowded areas as Lagos and Kano top the list with highest number of confirmed cases. The two state have highest population figures and are regarded as major industrial areas in the country.

Figure 3 show that confirmed cases of COVID-19 began to rise rapidly from 17th April, 2020 and the number of discharged cases began to rise from 1 1st May, 2020 while the number of deaths recorded within the period is very low. Rise in the number of confirmed cases is due to crowded urban areas, high poverty level, poor healthcare system and overpopulation.

\section{Conclusion and Recommendations}

This study has been able to assess the level preparedness, detection and response to coronavirus outbreak in the country. It has also identified the risk factors and it is obvious that the fight against the virus involves everybody. Government, corporate bodies and philanthropists should collaborate to provide healthcare facilities and equipment necessary for testing, isolation and treatment of COVID-19 cases. Citizens should follow the guidelines as directed by the Federal Ministry of Health and Nigeria Centre for Disease Control (NCDC) to put an end to community transmission of the virus.

The following are recommended

- Improved healthcare system: Government should equip hospitals with basic facilities they need to function properly. The basic facilities should include more test kits, personal protective equipment, drugs and stable power supply. Health workers should also be motivated for them to perform optimally.

- Government should assist farmers with seedlings, fertilisers and soft loans to ensure food security in the country.

- Foreigners and citizens coming into the country should be isolated and tested that they are COVID-19-free before they are allowed to settle down

- Security agents should be given adequate facilities to patrol the country's international borders to prevent illegal border crossing to the country

\section{References}

i. National Population Commission (2010): Population Distribution by Sex, State, LGS and Senatorial Districts

ii. Nigeria Centre for Disease Control (2020): NCDC Daily reports on COVID-19 Outbreak in Nigeria. https://ncdc.gov,ng

iii. Nigeria Immigration Service: 2017 Annual Reporthttps://immigration.gov.ng/publications-newsletters/

iv. Migration Data Portal: https://migrationdataportal.org/data?i=stock_abs_\&t=2019 access date: 25 $5^{\text {th }}$ May 2020.

v. United Nations Development Programme (2020): The COVID-19 Pandemic in Nigeria. Potential Impact on the North East

vi. United Nations Development Programme (2020): The Impact of COVID-19 Pandemic in Nigeria. A Socio-Economic Analysis

vii. UNICEF (2018): Situation of Children and Women in Oyo State. An Atlas of Social Indicator 